\title{
COMITY AND JURISDICTIONAL RESTRAINT IN VANUATU
}

\author{
Reid Mortensen ${ }^{*}$
}

This article revisits Pacific Courts' treatment of two procedural tools for locating litigation in the best court: the doctrine of forum non conveniens and the anti-suit injunction. The recent reporting of the Vanuatu Court of Appeal's decision in Chan Wing (Vanuatu) Limited v Motis Pacific Lawyers shows that the court accepted orthodox principles for both procedures, representing an improvement in adjudication on the conduct of international litigation in the Pacific. Chan Wing also reveals a technique by which courts exercising the jurisdiction to grant anti-suit injunctions can unilaterally improve the enforceability of their own judgments in other countries. It is suggested that respect for international comity in Pacific Island adjudication has reached new heights in the principles stated in Chan Wing for the plea of forum non conveniens and the grant of anti-suit injunctions. However, it also seems that the Court of Appeal's efforts at enhancing the extraterritorial enforcement of its own judgments offends settled principles governing friendly and courteous relations between courts.

\section{JUDGING WHERE TO LITIGATE}

The growth of courts' international jurisdiction has given litigants greater choice in deciding where they will submit disputes. However, common law courts have also given themselves the power to make comparable decisions about where disputes will be litigated and, to that extent, to limit a litigant's preferences about where disputes will be determined. Accordingly, courts in common law countries now have the ability - albeit a limited one - to decide where in the world it is best that litigation be conducted and adjudged. The doctrine of forum non conveniens is one means by which this can occur, and the anti-suit injunction the other.

Lord Goff of Chievely, whose landmark speech in the Spiliada case brought the doctrine of forum non conveniens into English law, ${ }^{1}$ claimed that it was one of the most "civilised" of

\footnotetext{
Senior Lecturer in Law, University of Queensland.

1 Spiliada Maritime Corporation v Cansulex Limited [1987] 1 AC 460, 466-88 (HL) [Spiliada].
} 
legal principles. $^{2}$ It requires a court itself to exercise proportion in the broader international jurisdiction it has a right to claim and so, at times, willingly to decline to hear a case that a plaintiff brings before it. In general, the Spiliada doctrine demands that the court reach some conclusion as to whether it, or a relevant foreign court, is the natural forum for the litigation. If the court concludes that it is itself the natural forum then the litigation may proceed. However, if another court is thought to be the "more appropriate forum", then the local court should decline to hear the proceedings or order that they be stayed. The adoption of the doctrine of forum non conveniens in England made a deep impression on other Commonwealth courts, with the New Zealand, Fiji, Canadian and Singapore courts following suit. ${ }^{3}$ Furthermore a similar, though more restrictive, form of the doctrine was developed in Australia in Voth $v$ Manildra Flour Mills Pty Ltd, ${ }^{4}$ and later commended itself to the Supreme Court of Vanuatu. ${ }^{5}$ Under the Voth approach a court will decline jurisdiction only if it considers itself "a clearly inappropriate forum" for dealing with the litigation.

The other means available to a common law court to have international litigation placed in the best possible location is the anti-suit injunction. This enables a court, when it has the necessary control over parties to foreign litigation, to decide whether that litigation is being conducted in an appropriate court and, if not, to prohibit them from pursuing it there. ${ }^{6}$ In part, the principles for the granting of an anti-suit injunction incorporate those underlying the doctrine of forum non conveniens. Thus, a court should only enjoin litigation in a foreign court and give preference to litigating locally when it, the local court, concludes that by its own principles of forum non conveniens it is an appropriate court to deal with the litigation. Furthermore, the local court might also require the question of forum non conveniens to be put to the foreign court before the local court takes the drastic step of issuing an injunction to have the foreign proceedings discontinued. ${ }^{7}$

2 Airbus Industrie GIE v Patel [1999] 1 AC 119, 141 (HL) [Airbus].

$3 \quad$ Club Mediterranée NZ v Wendell [1989] 1 NZLR 216 (CA); Brinkerhoff Maritime Drilling Corporation $v$ PT Airfast Services Indonesia [1992] 2 SLR 776 (SC); Amchem Products Inc v British Columbia (Workers' Compensation Board) [1993] 1 SCR 897, 931 [Amchem]; Eng Liat Kiang v Eng Bak Hern [1995] 3 SLR 97 (CA); Translink Shipping Limited v Compagnie Wallisienne de Navigation SARL (1991) 37 Fiji LR 46 (HC)

$4 \quad$ Voth v Manildra Flour Mills Pty Ltd (1990) 171 CLR 538 [Voth].

$5 \quad$ Naylor v Kilham [1999] VUSC 11 (SC) [Naylor].

6 Société Nationale Industrielle Aerospatiale v Lee Kui Jak [1987] AC 871 (PC) [SNI Aerospatiale]; Amchem, above; CSR Limited v Cigna Insurance Australia Limited (1997) 189 CLR 345, 391 [CSR]; Airbus Industrie GIE v Patel [1999] 1 AC 119 (HL); Mount Kasi Limited v Range Resources Limited [1999] FJHC 57 (HC) [Mount Kasi]. 
In a recent edition of the Victoria University of Wellington Law Review, I considered how the doctrine of forum non conveniens and the principles for the granting of anti-suit injunctions had been adopted and applied in Fiji and Vanuatu courts. ${ }^{8}$ By accepting the availability of the plea of forum non conveniens and the anti-suit injunction, these courts endorsed the basic idea that, despite what a litigant might want, a court could decide where in the world the litigation was best conducted. Still, despite accepting both procedures, these courts failed to adopt or apply some subordinate principles that were directed towards maintaining procedural equality between the parties. Although it might be hazardous to suggest any consistent themes beneath this, in both Fiji and Vanuatu the significance of parallel proceedings in another country (or lis alibi pendens) was devalued. This suggested a reluctance on the part of the Pacific island courts to pay much, if any, attention to the relevant foreign court or the proceedings before it. In Fiji it appeared that an anti-suit injunction was granted merely because the Fiji court considered that it was itself the natural forum, ignoring the need to show that the foreign litigation was also either vexatious or oppressive to the foreign defendant. Furthermore, in Vanuatu the form of the doctrine of forum non conveniens adopted deferred strongly to a citizen or resident plaintiff's choice of court but denied that deference to a foreign plaintiff. ${ }^{9}$

These shortcomings came from decisions made in trial courts. The hope was expressed that, when these issues came before an appellate court in the Pacific, the appeal judges would give stronger guarantees that litigation be conducted in a procedurally neutral setting. ${ }^{10}$ The first public reporting in 2001 of Chan Wing (Vanuatu) Limited v Motis Pacific Lawyers, ${ }^{11}$ decided by the Vanuatu Court of Appeal in 1998, reveals that, unbeknown even to lawyers in Vanuatu, an appellate court in the Pacific had already done just that. A decision to issue an anti-suit injunction, Chan Wing deserves attention because it marks out important limiting principles that frame any exercise of international jurisdiction by a Vanuatu court and shows the working of the principle of comity in the rules that govern international litigation. In a more specific sense it enables, first, an update of the earlier discussion in this journal of principles relating to the appropriate forum in international litigation, and an explanation of how the Vanuatu court has brought discipline to the field. Second, dealing as it does with anti-suit injunctions, Chan Wing necessarily raises the question of forum non conveniens that is incorporated in the principles for the granting of

$8 \quad$ Reid Mortensen "Duty Free Forum Shopping: Disputing Venue in the Pacific" (2001) 32 VUWLR 673; also published at (2001) 6 Yearbook of the New Zealand Association for Comparative Law 673, and (2001) 7 Revue Juridique Polynesienne 673. Mortensen, above, 687-689, 697-699, 702-703.

10 Mortensen, above, 703.

11 Chan Wing (Vanuatu) Limited v Motis Pacific Lawyers [1998] VUCA 3 (CA) [Chan Wing]. 
injunctions against foreign proceedings. The Chan Wing court's approach to forum non conveniens differs significantly from an approach subsequently taken to the plea in Vanuatu, and requires some reconsideration of the status of the doctrine in that country. Third, the anti-suit injunction in Chan Wing not only addressed the conduct of foreign litigation. It partly addressed the enforcement in a foreign country of any local judgment obtained in the litigation. The earlier discussion in this journal concentrated on the question of jurisdiction in international litigation. This aspect of Chan Wing raises the equally important question of the international enforcement of judgments, and the limits that international comity should place on it.

\section{COMITY}

\section{A Origins}

As western jurisprudence refined the notion of law as the emanation of a sovereign's will, early international lawyers needed some explanation as to why one country's courts might give effect to a foreign sovereign's laws. "Comity", understood no more precisely than a sentiment of friendship and courtesy between sovereigns, was commonly raised as an explanation of one country's motives for recognising legal rights acquired in another. ${ }^{12}$ This, however, offered little guide as to the conditions on which foreign laws and rights might be recognised locally. Even Dicey, writing sympathetically within the tradition of comity theorists, was concerned that grounding decisions made in international cases in the idea of comity might allow judges, at a whim, to recognise or to refuse recognition to foreign legal rights out of mere caprice or favour. Though he doubted theorists who advocated an international legal obligation to give principled recognition to foreign legal rights, Dicey was also sceptical that comity could dictate more specific conditions that would indicate when a local court should give effect to foreign rights. ${ }^{13}$ However, by the end of the nineteenth century American courts had given more specific content to the idea of comity, holding that it was "neither a matter of absolute obligation, on the one hand, nor of mere courtesy and goodwill, upon the other". ${ }^{14}$ It was the recognition of foreign legal rights, "having due regard to both international duty and convenience, and to the rights of its own citizens or of other persons who are under the protection of its laws". ${ }^{15}$ That approach still has support, ${ }^{16}$ although it leaves the idea of comity at a high level of

12 U Huber De Conflictu Legum II iii; see EG Lorenzen Selected Articles in the Conflict of Laws (Yale University Press, New Haven, 1947) 164; J Story Commentaries on the Conflict of Laws (2 ed, Maxwell, London, 1841) 38-43.

13 AV Dicey The Conflict of Laws (1st ed, Stevens \& Sons, London, 1896) 10-11.

14 Hilton $v$ Guyot (1895)159 US 113, 163-4 (SC).

15 Hilton v Guyot (1895)159 US 113, 163-4 (SC).

16 See CSR Limited v Cigna Insurance Australia Limited (1997) 189 CLR 345, 395-396. 
abstraction. It has nevertheless helped to define two more specific senses in which courts have given practical effect to the idea of comity, that are relevant to this discussion.

\section{B Comity and Anti-suit Injunctions}

In relation to anti-suit injunctions, comity is invoked to emphasise the need for exercising special caution before granting them. ${ }^{17}$ Some have questioned whether the granting of the injunction could ever offend the foreign court that was entertaining the proceedings that were restrained. ${ }^{18}$ However, the law reports reveal cases where an antisuit injunction has caused insult, and it must always present some risk of souring friendly and courteous relations between courts. ${ }^{19}$ To minimise this risk, therefore, it is settled law that, as one precondition to the grant of an anti-suit injunction, the local court must demand the plaintiff prove that the foreign proceedings are vexatious and oppressive. ${ }^{20}$ Accordingly, despite Dicey's doubts that it could do so, comity has spawned a precise rule for determining when a court should not allow foreign proceedings to continue.

\section{Comity and the Enforcement of Foreign Judgments}

A second sense in which comity has taken on a more specific meaning arises in relation to the recognition and enforcement of foreign judgments. Usage from the eighteenth century here gave comity "overtones" of reciprocity, ${ }^{21}$ although reciprocity in two distinct respects. First, as the English courts tended to understand it, the theory of comity could require the local court to enforce a foreign judgment if, when rendering the original judgment, the foreign court was exercising a jurisdiction that the local court arrogated to itself in similar cases. So, if the English courts were prepared to exercise jurisdiction in a divorce case because the petitioner was resident in England, they would recognise a

17 See CSR, above, 396.

18 AS Bell \& J Gleeson "The Anti-suit Injunction" (1997) 71 ALJ 955, 968.

19 Reid Mortensen "Duty Free Forum Shopping: Disputing Venue in the Pacific" (2001) 32 VUWLR 673; also published at (2001) 6 Yearbook of the New Zealand Association for Comparative Law 673; and (2001) 7 Revue Juridique Polynesienne 699.

20 Société Nationale Industrielle Aerospatiale v Lee Kui Jak [1987] AC 871, 932 (PC) [SNI Aerospatiale]; Amchem Products Inc v British Columbia (Workers' Compensation Board) [1993] 1 SCR 932; CSR Limited v Cigna Insurance Australia Limited (1997) 189 CLR 390, 393 [CSR]. Compare with TC Hartley 'Comity and the Use of Antisuit Injunctions' (1987) 35 Am Comp Law 487, 507-8, where a stricter approach to the granting of these injunctions is recommended, and it is argued that the vexatiousness of foreign proceedings is usually capable of being addressed by remedies available in the foreign court.

21 Alexander E Anton Private International Law: a Treatise from the Standpoint of Scots Law (2nd ed, W Green, Edinburgh, 1990) 220. 
divorce made in New South Wales when the petitioner was resident in that State. ${ }^{22}$ Alternatively, reciprocity might not be required in the jurisdictions that local and foreign courts could exercise, but more directly in the conditions that each country had set for the recognition and enforcement of each other's judgments. Dicey's disciple Joseph Beale understood comity in this limited sense, ${ }^{23}$ and it is how comity is understood under legislative schemes that ease the enforcement of foreign judgments by registration. Those countries that model enforcement of judgments legislation on the Foreign Judgments (Reciprocal Enforcement) Act 1933 (UK) will make judgments rendered in specified foreign countries enforceable by registration in a local court because those foreign countries have also made local judgments enforceable there by registration.

It turns out that, at common law, comity has largely been trumped by the theory of obligation as a reason for enforcing foreign judgments. The accepted rationale for enforcing a foreign judgment is now that, when first made, the judgment creates an obligation on the part of the defendant to pay a sum to the plaintiff, which in certain conditions is enforceable locally by an action in debt. ${ }^{24}$ This does not deny that, in relation to the international enforcement of judgments, "comity" largely means reciprocity, although it does reject reciprocity as the legal justification for the local enforcement of foreign judgments. Still, reciprocity remains the determining condition for the special treatment of a foreign country's judgment under enforcement of judgments legislation.

\section{THE CHAN-WING DECISION}

\section{A Coral Sea Legal Battles}

Like all other cases involving an anti-suit injunction, the actual decision in Chan Wing (Vanuatu) Limited $v$ Motis Pacific Lawyers was preceded by related legal proceedings in different places. Motis Pacific Lawyers, a law firm in Port Vila, had undertaken work for two Vila residents, Laurie and Karen Chan, in relation to the purchase of a nightclub in the city. In May 1997, the Vanuatu proceedings were commenced. Motis sued the Chans and Vanuatu registered companies they controlled for just under VT4.9 million (or about $\mathrm{NZ} \$ 80,000)$ to recover claimed professional fees and outlays for undertaking the work. This action was brought in the Supreme Court of Vanuatu, which also granted a Mareva injunction against the Chans to ensure enough was available in Vanuatu to satisfy any

22 Travers $v$ Holley [1953] 2 All ER 794 (CA); see also Hilton $v$ Guyot (1895)159 US 113 (SC); Re Dulles Settlement (No 2) [1951] Ch 842, 851 (CA).

23 American Law Institute Restatement of the Law of Conflict of Laws (American Law Institute Publishers, St Paul, 1933) 10-11.

24 Anton, above, 221; Lawrence Collins Dicey and Morris on the Conflict of Laws (12th ed, Sweet \& Maxwell, London, 1993) 486-488; PM North \& JJ Fawcett Cheshire \& North's Private International Law (12th ed, Butterworths, London, 1992) 346. 
judgment that might be awarded to Motis. The Chans later challenged the granting of the Mareva, but nothing turns on that application.

In July 1997 the Chans began the Queensland proceedings. They sued Ronald Moti, a partner of Motis, in the Supreme Court of Queensland, claiming breach of contract, negligence, deceit, fraud, detinue and conversion. The claims arose out of Moti's representing the Chans in the purchase of the Vila nightclub. Moti did not enter an appearance to the Queensland proceedings, and a default judgment for more than A $\$ 190,000$ (or about NZ\$230,000) was entered against him. In Australia a judgment of one State's courts is easily enforced in another State by registration, ${ }^{25}$ and the Chans then sought to enforce the Queensland judgment against assets that Moti held in New South Wales.

That brought Moti into the Queensland proceedings for the first time. In March 1998, he applied to Chesterman J in the Queensland Supreme Court - successfully - to have the default judgment set aside. That was also enough to make the Queensland judgment unenforceable in New South Wales. ${ }^{26}$ Moti also asked Chesterman J to stay the proceedings on the ground that the Queensland court was a forum non conveniens, but this was refused. At that point, Moti entered an appearance in Queensland. However, in May 1998 he applied to Lunabek ACJ in the Vanuatu Supreme Court to have an anti-suit injunction issued against the Chans and their companies, prohibiting them from continuing the Queensland proceedings. Lunabek ACJ granted this, restraining the Chans: ${ }^{27}$

... from commencing or causing to be commenced and from continuing or prosecuting or causing to be continued or prosecuted proceedings (including proceeding for enforcement of any judgment obtained in default of appearance or defence) against [Motis or any partner of the firm] in the Supreme Court of Queensland, the Supreme Court of New South Wales and any other Court in the Commonwealth of Australia or elsewhere out of the Jurisdiction of the Court in respect of any claim relating to certain professional services rendered to [the Chans or their companies].

Lunabek ACJ's decision to grant that injunction was upheld on appeal, the Court of Appeal comprising Von Doussa, Fatiaki and Marum JJ.

\footnotetext{
25 Under Service and Execution of Process Act 1992 (Cth) s 105(2).

26 Service and Execution of Process Act 1992 (Cth) s 105(5).

27 Chan Wing (Vanuatu) Limited v Motis Pacific Lawyers [1998] VUCA 3 (CA) para 1 [Chan Wing].
} 


\section{B Anti-suit Injunctions: Outline of Principles}

The Court of Appeal adopted an orthodox approach when formulating principles for the granting of anti-suit injunctions by Vanuatu courts. In fact, it accepted the leading decision of the Privy Council in Société Nationale Industrielle Aerospatiale v Lee Kui Jak ${ }^{28}$ without criticism or revision. The principles of SNI Aerospatiale had been refined in subsequent decisions in Canada ${ }^{29}$ and Australia, ${ }^{30}$ although without any fundamental structural change. ${ }^{31}$ As a consequence, the Court of Appeal aligned the law of Vanuatu with that of other Commonwealth countries.

The court held that there are two broad requirements that must be met before an antisuit injunction is awarded. First, the local court must decide that it is, under principles of forum non conveniens, an appropriate court for the determination of the proceedings. As the court put it in Chan Wing, "the Vanuatu Court must conclude that it provides the natural forum for the trial of the action". ${ }^{32}$ Second, in keeping with principles of comity the local court must also be satisfied that it would be vexatious or oppressive to allow the foreign plaintiff to pursue the foreign proceedings. Again, as the Chan Wing court expressed this principle: "the Vanuatu Court will, generally speaking, only restrain the Defendant from pursuing the proceedings in the foreign court if such pursuit would be vexatious or oppressive". 33 This means that "account must be taken not only of injustice to the Plaintiff [if] the Defendant is allowed to pursue the foreign proceedings, but also of injustice to the Defendant if he is not allowed to do so". 34 "So, as a general rule, the court will not grant an injunction if, by doing so, it will deprive the Defendant of advantages in the foreign forum of which it would be unjust to deprive him". ${ }^{35}$

28 Société Nationale Industrielle Aerospatiale v Lee Kui Jak [1987] AC 871 [SNI Aerospatiale]; Amchem Products Inc v British Columbia (Workers' Compensation Board) [1993] 1 SCR 897, 931 [Amchem]; CSR Limited v Cigna Insurance Australia Limited (1997) 189 CLR 345, 391 [CSR]; Airbus Industrie GIE v Patel [1999] 1 AC 119, 141 (HL) [Airbus]; Mount Kasi Limited v Range Resources Limited [1999] FJHC 57 (HC) [Mount Kasi].

29 Amchem, above.

30 CSR, above.

31 No mention was made of the Canadian and Australian developments in Chan Wing (Vanuatu) Limited $v$ Motis Pacific Lawyers [1998] VUCA 3 (CA) para 1 [Chan Wing]. The English decision in Airbus Industrie GIE v Patel [1999] 1 AC 119, 141 (HL) [Airbus] was delivered afterwards.

32 Chan Wing, above.

33 Chan Wing, above, para 14.

34 Chan Wing, above, para 14.

35 Chan Wing, above, para 14. 
In one respect, the court confused the first requirement that the local court conclude that it is an appropriate court with a precaution ventured by the Supreme Court of Canada in Amchem Products Inc v British Columbia (Workers' Compensation Board). ${ }^{36}$ The Amchem precaution was that it was "preferable" that the local plaintiff apply for a stay of proceedings in the foreign court before being allowed to seek an anti-suit injunction in the local court. ${ }^{37}$ The High Court of Australia had re-presented this idea in CSR Limited $v$ Cigna Insurance Australia Limited, refusing to concede that it was a "general rule" but recognising that "[t]here may be cases" where "it is appropriate or desirable" to demand that the local plaintiff have first asked the foreign court to stay or dismiss the foreign proceedings on the ground of forum non conveniens. ${ }^{38}$ The plaintiffs in Chan Wing had done this, asking the Supreme Court of Queensland to stay the proceedings before it. This the Queensland court refused, effectively ruling that it was an appropriate court to hear the case. The Vanuatu Court of Appeal thought that the Queensland court might have decided otherwise if it had been aware of the earlier proceedings in Vanuatu. ${ }^{39}$ However, it assumed that the Queensland court's conclusion that it was an appropriate court to deal with the case was potentially incompatible with the Vanuatu court's issuing an anti-suit injunction, as this depended on a conclusion that the Vanuatu court was the appropriate court to deal with the case. The Court of Appeal therefore cited Lord Goff in SNI Aerospatiale, where he said: ${ }^{40}$

Their Lordships ... can find no trace of any suggestion that the principles applicable in cases of stays of proceedings and in cases of injunction are the same.

However, Lord Goff was not here referring to the position where the foreign court had accepted that it - the foreign court - was an appropriate court. He was referring to the position where the local court had reached the conclusion that the local court was an appropriate court. Indeed, where the plaintiff has pleaded forum non conveniens before the foreign court, it will only be possible to grant an anti-suit injunction when the foreign court has concluded that it - the foreign court - should hear the case. For if the foreign court

36 Amchem Products Inc v British Columbia (Workers' Compensation Board) [1993] 1 SCR 897, 931 [Amchem].

37 Amchem, above, 931.

38 CSR Limited v Cigna Insurance Australia Limited (1997) 189 CLR 397 [CSR].

39 Chan Wing (Vanuatu) Limited v Motis Pacific Lawyers [1998] VUCA 3 (CA) para 21 [Chan Wing].

40 Société Nationale Industrielle Aerospatiale v Lee Kui Jak [1987] AC 871, 899 (PC) [SNI Aerospatiale]; Chan Wing, above, para 14. 
concludes that it is a forum non conveniens and stays the proceedings, there will be no need for an anti-suit injunction to restrain them. ${ }^{41}$

In this passage Lord Goff was rejecting the principle of symmetry: the idea that, if a local court concludes that it is an appropriate court to deal with the case, then that is enough for it also to enjoin parallel proceedings before a foreign court. ${ }^{42}$ In $S \mathrm{NI}$ Aerospatiale and the later cases, it was emphasised that the principles applicable to stays of proceedings before the local court and the principles applicable to anti-suit injunctions made by the local court are not the same. ${ }^{43}$ Owing to its greater risk of compromising the principle of comity, more is needed to grant the anti-suit injunction, and that is the second requirement that the local court also be satisfied that it would be vexatious or oppressive to allow the foreign proceedings to continue.

Despite misconceiving Lord Goff's comparison of principles applicable to forum non conveniens and anti-suit injunctions, the Chan Wing court closely followed his requirements for the granting of the injunction. There is little doubt that the Supreme Court of Vanuatu was the most appropriate court for the determination of the proceedings. Motis were primarily based in Vanuatu, and the Chans' companies were incorporated and had their registered offices there. The contract for the retention of Motis and the contract for the purchase of the nightclub were made in Vanuatu, and governed by Vanuatu law. The nightclub itself was in Port Vila. ${ }^{44}$ This litigation was essentially domestic to Vanuatu. In contrast, the connections with Queensland were tenuous. Nevertheless, this did not enter the Court of Appeal's assessment that the Queensland proceedings were vexatious and oppressive, the second prerequisite to the granting of the anti-suit inunction. The "exceptional" considerations in Chan Wing centred on the fact that this was a dispute between Vanuatu solicitors and their clients, potentially raising the disciplinary jurisdiction of the Vanuatu court over its officers; the taxation of the solicitors' costs by Vanuatu taxing authorities; and the public interest in having Vanuatu courts deal with the

41 Hartley considers that, in this situation, comity demands that the local court defer to the foreign court's conclusion that it is a forum conveniens. Accordingly, he recommends against grantijng an anti-suit injunction in this case: TC Hartley 'Comity and the Use of Antisuit Injunctions' (1987) 35 Am Comp Law 487, 507-8, where a stricter approach to the granting of these injunctions is recommended, and it is argued that the vexatiousness of foreign proceedings is usually capable of being addressed by remedies available in the foreign court.

42 R Mortensen "Duty Free Forum Shopping: Disputing Venue in the Pacific" (2001) 32 VUWLR 673; also published at (2001) 6 Yearbook of the New Zealand Association for Comparative Law 673; and(2001) 7 Revue Juridique Polynesienne 691.

43 Mortensen, above, 691-692.

44 Chan Wing (Vanuatu) Limited v Motis Pacific Lawyers [1998] VUCA 3 (CA) para 15 [Chan Wing]. 
professional standards of Vanuatu lawyers. ${ }^{45}$ As had been recognised in the judgment, the court also had to consider whether restraining the foreign proceedings would unjustly deprive the local defendant of any advantages. Although the Chans claimed that they had experienced greater delays in Vanuatu and that a witness to the nightclub purchase could not be forced to give evidence there, the court doubted that these formed the basis of any material advantage to the Chans that would be lost if the Queensland proceedings were restrained. ${ }^{46}$ Accordingly, the court thought that Lunabek ACJ had properly exercised his discretion in granting the anti-suit injunction. ${ }^{47}$

The approach taken to anti-suit injunctions in Chan Wing contrasts favourably against that taken by Byrne $\mathrm{J}$ in the High Court of Fiji in Mount Kasi Limited $v$ Range Resources Limited, where the need to show that the foreign proceedings were vexatious and oppressive was ignored. ${ }^{48}$ In Mount Kasi Byrne J granted an anti-suit injunction to end proceedings before the Supreme Court of Western Australia, merely on concluding that the Fiji court was the appropriate forum for the determination of the dispute. ${ }^{49}$ While the court in Mount Kasi stated expressly that there was still a need to show that the foreign proceedings were vexatious and oppressive, ${ }^{50}$ it concluded that "the commencement of proceedings in a forum having little or no connection with the subject matter of the dispute is generally regarded as an indication of vexatiousness or oppression". 51 However, no effort was taken to determine the kind of connection the Western Australia court had with the proceedings. It seems that Byrne $\mathrm{J}$ tacitly assumed that, merely because the Fiji court was the natural forum, the Western Australia court had "little or no connection" with the question in dispute and, so, the proceedings before it were vexatious and oppressive. In short, in Mount Kasi an anti-suit injunction issued because the Fiji court found that it - the Fiji court - was the forum conveniens, and nothing more was needed. This was applying the principle of symmetry that Lord Goff had rejected in SNI Aerosptiale. ${ }^{52}$ In Chan Wing, both Lunabek ACJ and the Court of Appeal took other considerations into account. The Vanuatu court, as it must, had accepted that it was the appropriate court for a dispute that

$45 \quad$ Chan Wing, above, para 17.

46 Chan Wing, above, paras 18-20.

47 Chan Wing, above, paras 21-22.

48 Mount Kasi Limited v Range Resources Limited [1999] FJHC 57 (HC) [Mount Kasi].

49 Mount Kasi, above, para 37.

50 Mount Kasi, above, para 30.

51 Mount Kasi, above, para 31.

52 Reid Mortensen "Duty Free Forum Shopping: Disputing Venue in the Pacific" (2001) 32 VUWLR 673; also published at (2001) 6 Yearbook of the New Zealand Association for Comparative Law 673; and (2001) 7 Revue Juridique Polynesienne 697-699. 
was, in substance, domestic to Vanuatu. But, in addition to that, other matters like the central interest that a Vanuatu court has in dealing with matters relating to the conduct of its own lawyers and the absence of any material advantage to the Chans in proceeding in Queensland justified a conclusion that this case involved more than enjoining proceedings in a court that was, from the Vanuatu perspective, a forum non conveniens.

A second favourable contrast to Mount Kasi was the willingness of the Vanuatu court to weigh the significance of the proceedings pending in the foreign court (lis alibi pendens). As discussed in the earlier article in this journal, the trend in adjudication in the Pacific islands has been to devalue the significance of lis pendens when making decisions about the best place to litigate and, indeed, to pay almost no attention to the foreign court or proceedings before it. ${ }^{53}$ In Chan Wing though, the court closely analysed the Queensland proceedings. Though probably misconceiving how it was relevant, the unsuccessful plea of forum non conveniens in Queensland was examined carefully in an effort to explain how the Queensland court could be considered from the Vanuatu perspective to be a less appropriate forum when the Queensland court had itself decided that it was an appropriate court to deal with the case. Material advantages available to the local defendant in the Queensland proceedings were also weighed. Accordingly, although both Mount Kasi and Chan Wing saw the issue of an anti-suit injunction, the procedure adopted in Chan Wing ensured that it was only in a clearer case of illegitimate forum shopping that the drastic step of restraining foreign proceedings was taken.

\section{FORUM NON CONVENIENS RECONSIDERED}

Equally, if not more, significant than the decision on anti-suit injunctions in Chan Wing is the necessary implication it has for the statement of the doctrine of forum non conveniens in Vanuatu. Lunabek ACJ's later decision (though reported earlier) in Naylor $v$ Kilham saw him adopt the more restrictive Australian form of the doctrine of forum non conveniens stated in the Voth case. ${ }^{54}$ In Naylor, Lunabek ACJ compared this to the Spiliada approach to forum non conveniens, by which proceedings are stayed if the local court considers that another court is "clearly or distinctly more appropriate" for the determination of the dispute than the local court. ${ }^{55}$ Accepting that the Voth approach was "preferable", he concluded that "a Vanuatu Court is to exercise its traditional power to stay proceedings when the defendant convinces the Court that it is a 'clearly inappropriate forum"'. ${ }^{6}$ The result was that, in Naylor, a stay of proceedings in Vanuatu was refused - even though the

53 Mortensen above, 685-688, 702

$54 \quad$ Naylor v Kilham [1999] VUSC 11 (SC) [Naylor].

55 Naylor, above, para 10.

56

Naylor, above, para 12; citing Voth v Manildra Flour Mills Pty Ltd (1990) 171 CLR 538, 558 [Voth]. 
proceedings brought by the plaintiff in Vanuatu replicated a claim the plaintiff herself had earlier commenced in the United States, and the American court was likely to enter judgment before the Vanuatu court did.

The approach taken to forum non conveniens in Naylor is exposed to all of the criticisms that the Voth approach has already met in the literature. Oddly, some have claimed that it will almost always lead to the same result in a forum non conveniens application than the Spliliada doctrine would, which begs the question why it was then necessary for the Voth court to go to some length to state a different principle. ${ }^{57}$ If the different form of the Voth approach is nevertheless given more than lip service, it is certainly more plaintiff-oriented than the Spiliada doctrine and, so, provides greater opportunities for forum shopping. ${ }^{58}$ Furthermore, it is internationally idiosyncratic, and practice based on Voth fails to conform to that in other Commonwealth countries and, for the most part, that in the United States. ${ }^{59}$ Finally, it has proved inadequate for dealing with questions like lis pendens and exclusive jurisdiction clauses, and has had to be adjusted to conform more closely to the Spiliada doctrine. ${ }^{60}$ The principles espoused in Naylor have already been criticised for a number of additional reasons that compound the plaintiff-orientation inherent in the Voth approach. First, the Vanuatu court refused to allow the defendant even to raise the question why the American proceedings should be preferred. ${ }^{61}$ Second, the question of $l$ is pendens was ignored completely. Naylor was a strong case for a stay on the ground of $l$ is pendens. The plaintiff in Vanuatu was also the plaintiff in the United States, meaning that the defendant was "doubly vexed" by the plaintiff once the Vanuatu proceedings were commenced. ${ }^{62}$ Third, the court adopted a "foreign plaintiff" rule. Effectively, this meant that the court would be much more likely to defer to the plaintiff's choice of court where the local plaintiff was a local citizen or resident. The converse, as Lunabek ACJ put it in Naylor, is that "[a] foreign Plaintiff is not necessarily entitled to the same Court access as a

57 P Brereton 'Forum Non Conveniens in Australia: A Case Note on Voth v Manildra Flour Mills' (1991) 40 ICLQ 895, 898; A Mason 'Changing the Law in a Changing Society' (1993) 67 ALJ 568, 572 .

58 Lawrence Collins 'The High Court of Australia and Forum Conveniens: The Last Word?' (1991) 107 LQR 182, 187; MC Pryles 'Forum Non Conveniens - The Next Chapter' (1991) 65 ALJ 442, 450; Peter E Nygh Conflict of Laws in Australia (6th ed, Butterworths, Sydney) 108.

59 Nygh, above, 108.

60 R Garnett 'Stay of Proceedings in Australia: A "Clearly Inappropriate" Test' (1999) 23 Melbourne University Law Review 30, 63.

61 R Mortensen "Duty Free Forum Shopping: Disputing Venue in the Pacific" (2001) 32 VUWLR 673; also published at (2001) 6 Yearbook of the New Zealand Association for Comparative Law 673; and (2001) 7 Revue Juridique Polynesienne 686.

62 Mortensen, above, 687-8. 
resident or a citizen". ${ }^{63}$ This creates a procedural bias to claims brought by residents or nationals and, if Naylor is any guide, makes it almost impossible to obtain a stay of proceedings brought by residents or nationals. Furthermore, as the ability to sue is a precondition to the vindication of legal rights, a procedural preference for locals can amount to a substantive preference for them. ${ }^{64}$

These criticisms highlight policies that suggest it would be better that Naylor $v$ Kilham not be followed in Vanuatu. Chan Wing provides another reason for interring Naylor. The Court of Appeal's decision indicates that Naylor was decided per incuriam. The doctrine of forum non conveniens that courts in Vanuatu must apply is the now well-accepted Spiliada doctrine that a stay of proceedings is granted if the relevant foreign court is the natural forum for the litigation, in the sense that it is a clearly more appropriate court for the determination of the dispute.

As has been seen, the Chan Wing court held that the first requirement for the granting of an anti-suit injunction was that the Vanuatu court be satisfied that it was the "natural forum" for the litigation. ${ }^{65}$ That followed once the court embraced the principles that Lord Goff had stated in SNI Aerospatiale, including the need for the local court to "conclude that it provides the natural forum for the trial of the action". ${ }^{6}$ In SNI Aerospatiale, Lord Goff was incorporating the form of the doctrine of forum non conveniens that he had stated the previous year in Spiliada. ${ }^{67}$ The term "natural forum" was used in Spiliada to describe the court "with which the action had the most real and substantial connection", 68 this being identified by matters going to convenience and expense (including the availability of witnesses), the places where the parties reside or carry on business, and the law governing the proceedings. ${ }^{69}$ The "natural forum" was also referred to as the "appropriate forum for the trial", the "forum which is prima facie the appropriate forum for the trial of the action", and the "forum which is clearly or distinctly more appropriate than the [local] forum". ${ }^{70}$ All things considered, the natural forum is the more appropriate court for the hearing of the litigation. So, if the local court is the natural forum, a stay of proceedings is ordinarily

63 Naylor $v$ Kilham [1999] VUSC 11 (SC) paras 8-9 [Naylor].

64 Mortensen, above, 688-689.

65 Chan Wing (Vanuatu) Limited v Motis Pacific Lawyers [1998] VUCA 3 [Chan Wing] (CA) para 14.

66 Société Nationale Industrielle Aerospatiale v Lee Kui Jak [1987] AC 871, 896 (PC) [SNI Aerospatiale].

67 Spiliada Maritime Corporation v Cansulex Limited [1987] 1 AC 460, 466-88 (HL) [Spiliada]; see SNI Aerospatiale, above, 891, 895.

68 Spiliada, above, 478, citing Lord Keith of Kinkel in The Abidin Daver [1984] AC 398, 415 (HL).

69 Spiliada, above, 478.

$70 \quad$ Spiliada, above, 476, 477. 
refused. If the foreign court is the natural forum, a stay is granted unless the circumstances are such that it would be just to refuse it. ${ }^{71}$

This can be contrasted with the principles adopted in respect of anti-suit injunctions in the one Commonwealth country where, at the time Chan Wing was decided, the Spiliada approach to the doctrine of forum non conveniens had been rejected. When the High Court of Australia considered the granting of anti-suit injunctions in the CSR case, it too accepted that two broad requirements had to be satisfied - the local court must conclude that it is an appropriate court to exercise jurisdiction in the primary dispute being litigated and, further, the foreign proceedings must be vexatious and oppressive. ${ }^{72}$ However, the High Court emphatically denied that, in assessing whether the local court was the appropriate court, the Spiliada search for the natural forum was to be undertaken. ${ }^{73}$

... [T]he power to grant anti-suit injunctions should not be exercised without the court concerned first considering whether its own proceedings should be stayed.

The test which, in [Australia], governs a stay of proceedings in another country is as stated in Voth $v$ Manildra Flour Mills Ltd. In that case, this Court declined to adopt the more appropriate forum test laid down by the House of Lords in Spiliada Maritime Corp $v$ Cansulex Ltd and accepted, instead, ... that a stay is only to be granted if the Australian court is a clearly inappropriate forum.

Later in CSR, the High Court majority reiterated that "before granting an anti-suit injunction, an Australian court should consider whether it is an appropriate forum, in the Voth sense, for the resolution of the matter in issue or, if there be a difference, the matter advanced in support of the injunction". ${ }^{74}$

It is therefore evident from both SNI Aerospatiale and CSR that there is an inseverable nexus between the principles of forum non conveniens and anti-suit injunctions. In considering the first precondition to the granting of an anti-suit injunction that the local court be an appropriate one for dealing with the litigation, the local court must assess its own appropriateness by reference to the content of the underlying doctrine of forum non conveniens prevailing in its own country. The converse also applies. If the principles for the granting of anti-suit injunctions incorporate a specific form of the doctrine of forum non

\footnotetext{
$71 \quad$ Spiliada, above, 478 .

72 CSR Limited v Cigna Insurance Australia Limited (1997) 189 CLR 345, 391 [CSR].

73 CSR, above, 390-391.

74 CSR, above, 398.
} 
conveniens, then that would appear to be the form of the doctrine that would be applied in applications for stays or dismissals of proceedings before the local court. ${ }^{75}$

As a consequence, in Chan Wing the Vanuatu Court of Appeal adopted the Spiliada doctrine of forum non conveniens - a conclusion not affected by the fact that it did so in a case dealing with anti-suit injunctions. The decision that the Vanuatu court was the natural forum for the determination of the dispute was treated as material by the Court of Appeal and an essential basis of its decision to grant the injunction, and so qualifies as part of the reasons for decision in the case. ${ }^{76}$ The Spiliada doctrine is therefore an aspect of the ratio decidendi of Chan Wing and binding on trial judges in the Supreme Court. Accordingly, the court in Naylor $v$ Kilham was wrong to assume that there were open questions as to whether the doctrine of forum non conveniens was law in Vanuatu, and whether the Spiliada, Voth or some other form of the doctrine should prevail. ${ }^{77}$ From the time of the reporting of Chan Wing it can be safe to disregard the decision in Naylor $v$ Kilham.

\section{JUDGMENT ENFORCEMENT}

Once the injunction was granted in Chan Wing, it can be reasonably assumed that Vanuatu was the place where the dispute between the Chans and Motis would be dealt with. The setting aside of the default judgment in Queensland had already disabled its enforcement in New South Wales. The injunction, operating as a decree in personam against the Chans and their companies, would require them to discontinue the Queensland proceedings that had revived when the default judgment was set aside. If they did not discontinue in Queensland, they would be in contempt of court and exposed to imprisonment and sequestration. Altogether, that rightly located the litigation in Vanuatu. However, Ronald Moti evidently had assets in New South Wales and, it seems, in Queensland. So, assuming that the Chans could obtain judgment in Vanuatu against

75 The doctrine was recognised in Canada by this process. The Supreme Court of Canada has not considered a case that dealt only with stays or dismissals of proceedings on the ground of forum non conveniens. However, in Amchem it did consider principles for the granting of anti-suit injunctions and, holding that one requirement was that the local court had to determine that it was an appropriate court to deal with the dispute, adopted the Spliliada doctrine for assessing appropriateness: Amchem Products Inc v British Columbia (Workers' Compensation Board) [1993] 1 SCR 897 916-22 (SC) [Amchem]. Lower courts in Canada have considered that this demands application of the Spliliada principles when a stay or dismissal of proceedings is sought: see eg Upper Lakes Shipping Limited v Foster Yeoman Ltd (1993) 14 OR (3d) 548, 563-570 (CA); JG Castel Canadian Conflict of Laws (3rd ed, Butterworths, Toronto, 1994) 230-241.

76 This conclusion is based on Dr Goodhart's definition of the ratio decidendi, for which see R Cross \& JW Harris Precedent in English Law (4th ed, Clarendon Press, Oxford, 1991) 63-71.

77 Naylor v Kilham [1999] VUSC 11 (SC) paras 4, 10-11 [Naylor]. 
Motis, it would certainly help make the litigation worthwhile if they could enforce the Vanuatu judgment against the Australian assets.

\section{A Procedures for Enforcing Foreign Judgments}

There are two mutually exclusive procedures by which foreign judgments can be enforced in Australia and, for that matter, most Commonwealth countries. First, enforcement of a foreign judgment in Australia can take place by suing on it at common law as an ordinary debt, payable by the judgment debtor to the judgment creditor. ${ }^{78}$ The alternative procedure is registering the judgment in a superior court under the Foreign Judgments Act 1991 (Cth). ${ }^{79}$ However, the Foreign Judgments Act only allows the registration of judgments from courts mentioned in regulations made under the Act. ${ }^{80}$ Judgments capable of registration are not enforceable at common law. ${ }^{81}$ The circumstances in which a foreign judgment may be enforced at common law and by registration under the Act are nevertheless similar. Defences available to the judgment debtor and denying the right to enforcement are largely the same under either procedure: the foreign court lacked international jurisdiction; the judgment was obtained by fraud; there was a denial of natural justice; enforcement would be contrary to public policy; and so forth. ${ }^{82}$ The primary advantages that registration has over suing on the foreign judgment at common law are that it is less expensive, and there is no need for the enforcing court to have personal jurisdiction over the judgment debtor. When enforcing a foreign judgment at common law, the enforcing court must have the same personal jurisdiction over the defendant as it needs in any other action in debt. ${ }^{83}$ But a foreign judgment can be enforced against assets in the State by registration even when the judgment debtor is absent from the State and refuses to have anything to do with the enforcement proceedings. ${ }^{84}$

This dual approach to the enforcement of foreign judgments has parallels throughout the Commonwealth. Indeed Australia's Foreign Judgments Act follows the pattern of the

78 Reid G Mortensen Private International Law (Butterworths, Sydney, 2000) 324-34; Peter E Nygh Conflict of Laws in Australia (6th ed, Butterworths, Sydney) 137-61.

79 Mortensen, above, 335-45; Nygh, above, 162-70.

80 Foreign Judgments Act 1991 (Cth) s 5(1); Foreign Judgments Regulations 1993 (Cth) sch 1.

81 Foreign Judgments Act 1991 (Cth) s 10(1).

82 Mortensen, above, 325-334, 340-344; Nygh above, 153-161, 165-169.

83 Mortensen, above, 324.

84 Hunt $v$ BP Exploration Co (Libya) Ltd (1979) 144 CLR 565; Hunt v BP Exploration Co (Libya) Ltd [1981] 1 NZLR 209 (CA); English's Coasting and Shipping Co Ltd v British Finance Co Ltd (1886) 14 R 220 at 225-226 (Ct of Sess). 
Foreign Judgments (Reciprocal Enforcement) Act 1933 (UK), which has served as the dominant model for the enforcement of foreign judgments in many Commonwealth countries. ${ }^{85}$ New Zealand, Fiji, Solomon Islands, Papua New Guinea, Samoa and Tuvalu, amongst others, also have this form of enforcement of judgments legislation. ${ }^{86}$ This model does not make any foreign or Commonwealth judgment potentially registrable. It enables the judgments of courts of other countries to be added to a list of potentially registrable judgments when the Executive Government is satisfied that the foreign country will give "substantial reciprocity of treatment" for the enforcement of the judgments of its own courts in that foreign country. ${ }^{87}$ Accordingly, the criteria for special treatment of foreign judgments under the registration legislation rest on the old theory of comity, understood as reciprocity in the conditions for enforcing each country's judgments.

Vanuatu judgments are not registrable under Australia's Foreign Judgments Act, or in any other country that participates in the Commonwealth scheme based on the British Act of 1933. The reason is that Vanuatu refuses to offer any other country substantial reciprocity for the enforcement of judgments. That, of course, would require legislation allowing the enforcement of foreign judgments in Vanuatu by registration, and Vanuatu will not have this. ${ }^{88}$ This reluctance is symptomatic of a general scepticism in Vanuatu towards international legal cooperation. While official reasons are not given, the likelihood is that Vanuatu's legal parochialism is related to the country's promotion of itself as a tax haven. Foreign judgments certainly appear to be enforceable in Vanuatu at common law. However, so far as enforcement by registration is concerned, the Government may believe that Vanuatu is more attractive as a refuge for the funds of offshore business interests if foreign judgments cannot be enforced against local bank accounts held by absent depositors. ${ }^{89}$

85 Mortensen, above, 334; Nygh, above, 162.

86 Reciprocal Enforcement of Judgments Act 1934 (NZ); Foreign Judgments (Reciprocal Enforcement) Act 1978 (Fiji); Reciprocal Enforcement of Judgements Act (PNG); Foreign Judgments (Reciprocal Enforcement) Act 1988 (SI); Reciprocal Enforcement of Judgements Act (Sam); Foreign Judgments (Reciprocal Enforcement) Act 1978 (Tv).

87 Foreign Judgments Act 1991 (Cth) s 5(1), (3), and (6); Reciprocal Enforcement of Judgments Act 1934 (NZ), ss 3(2), 3 A(1), and 3 B(1); Foreign Judgments (Reciprocal Enforcement) Act 1978 (Fiji), s 3(1); Reciprocal Enforcement of Judgments Act (PNG), s 2(1); Foreign Judgments (Reciprocal Enforcement) Act 1988 (SI), s 3(1); Foreign Judgments (Reciprocal Enforcement) Act 1978 (TV), s 3(1).

88 Naylor v Kilham [1999] VUSC 11 (SC) para 7 [Naylor].

89 Similarly, Nauru and Kiribati, two other Commonwealth countries in the region that promote themselves as tax havens, do not offer enforcement of foreign judgments by registration. 


\section{B Unilateral Extension of Local Judgments}

In this light, the efforts the Chan Wing court took to improve the extraterritorial enforceability of any judgment obtained against Motis in the Vanuatu proceedings become more interesting. The court, having sustained Lunabek ACJ's anti-suit injunction against the Chans, imposed conditions on Motis that were aimed at improving the efficiency and effectiveness of the Vanuatu proceedings for the Chans. ${ }^{90}$ One of these was that Motis undertook: ${ }^{91}$

that in the event that Judgment is obtained against [Motis] by [the Chans] in the Vanuatu proceedings [Motis] will not seek to challenge the registration of the Judgment in Australia or the proper implementation of enforcement actions by [the Chans] in Australia against property of [Motis] or any partner thereof.

The fact that a Vanuatu judgment cannot be registered in Australia can be put to one side. It would have been potentially enforceable at common law by "enforcement actions ... against property of" any of the partners of Motis. So, even though the Chans were prohibited from litigating the primary claim in Queensland and enforcing a Queensland judgment against Ronald Moti's Australian assets, the requirement that they centre their litigation in Vanuatu was not to disadvantage them by limiting the accessibility of any Australian assets. If they were to be granted their preference to litigate only in Vanuatu, Motis had to surrender any rights they had to raise any defences (like fraud, denial of natural justice or public policy) that might be available to them in enforcement proceedings in Australia. The effect of this condition therefore seems to be that Motis volunteered their Australian assets if they were needed to satisfy any Vanuatu judgment against them, or at least agreed to a consent judgment for a claim brought by the Chans in an Australian court on a Vanuatu judgment debt. Accordingly, this condition seems to make the enforcement of a Vanuatu judgment easier in Australia than would even be the case if it were registrable there under the Foreign Judgments Act. Extraordinarily, this enhanced enforceability of a Vanuatu judgment in Australia occurred by terms dictated from Vanuatu. This simple expedient intended that a Vanuatu judgment become more easily enforced against Australian assets than even the forbidden Queensland judgment might have been.

This condition may have been nothing more than a symbolic gesture, as there is no evidence from the report in Chan Wing to suggest that the Chans, who were the defendants in the Vanuatu proceedings, had counterclaimed against Motis for damages. Success for the Chans in Vanuatu only meant that they were not liable to pay Motis the claimed

90 Chan Wing (Vanuatu) Limited v Motis Pacific Lawyers [1998] VUCA 3 (CA) para 22 [Chan Wing].

91 Chan Wing, above, para 23. 
professional fees and outlays, giving no need for them to move against Motis' assets in Vanuatu, Australia or anywhere else. That may well be best, as the condition arguably offends principles of international comity.

\section{Extraterritorial Enforcement of Judgment Against Plaintiff to Injunction}

At first glance, a condition easing the international enforcement of any judgment against Motis seems fair as it maximises the justice the court could do for both parties. Motis' decision to litigate at home was vindicated. The Chans retained the real advantage they had in litigating off-shore. Although the Chans were forced by the injunction to litigate only at home, Motis' foreign assets remained accessible to them. However, even these assessments of what is fair to both parties must be constrained by the overriding need in granting anti-suit injunctions to give effect to international comity.

While there is naturally no precise measure of what could be understood as a friendly and courteous policy so far as the extraterritorial enforcement of judgments is concerned, some account must be taken of the traditional sense of comity, when used in relation to the international enforcement of judgments, as having overtones of reciprocity. Any means by which a country can assert its sovereignty in another (by the enforcement of its judgments there) which it would not, as a matter of principle, allow the other country to assert within its own borders (by the local enforcement of the other country's judgments) is arguably a compromise of comity. It is an undue incursion on the other country's sovereign right to determine the conditions on which coercive power can be exercised within its borders and to define "the rights of ... persons [such as defendants to enforcement proceedings] who are under the protection of its laws". ${ }^{92}$ So, while the Chan Wing condition might reasonably be seen as compensating the defendants for being forced to abandon litigation in other countries, it has the unfortunate effect of indirectly compromising the foreign country's sovereignty.

\section{$D$ Extraterritorial enforcement of judgment against defendant to injunction}

The argument against a local court unilaterally improving the international enforcement of its own judgments is even more compelling if a condition not to resist enforcement proceedings in a foreign country were imposed on the defendant. The Chan Wing court did not go this far. However, temporarily ignoring the question of comity, there would seem no reason why it would not have the power to impose this condition on a defendant. Given the circumstances of Chan Wing, a prohibitory injunction that restrained the defendant Chans from litigating in Australia could also restrain them from defending proceedings in Australia for the enforcement of any judgment obtained against them in Vanuatu. It is the same expedient that was imposed on the plaintiffs, but with the

$92 \quad$ Hilton $v$ Guyot (1895) 159 US 113, 164. 
greater threat that breach by a defendant to an injunction amounts to contempt of court where breach by a plaintiff only means loss of the injunction. Once again, the extraterritorial enforcement of the local judgment is improved by terms dictated by the local court rather than measures taken in the country of enforcement. Indeed, this condition raises the potential for any local court - asked to give specific relief against a defendant over whom it has in personam jurisdiction - to ease the extraterritorial enforcement of its own judgment by enjoining a defence to enforcement proceedings in a foreign country.

As in the case of a similar condition required of a plaintiff, this would probably compromise principles of comity. It claims for the local court a power to enforce its judgments internationally that the local court does not allow to foreign courts. In addition, it could not be justified as a means of balancing the interests of plaintiff and defendant as, perhaps, the same condition imposed on the plaintiff could. The defendant is forced to abandon his or her preferred forum and, further, to make foreign assets available for the satisfaction of any local judgment the plaintiff might obtain. The added unfairness of such a condition imposed on the defendant may explain why the Chan Wing court did not include this in the injunction, despite imposing it on the plaintiff. However, in the absence of any counterclaim by the defendant Chans against the plaintiff Motis, the question remains whether the condition imposed on the plaintiffs served any purpose at all.

\section{CONCLUSION}

The Vanuatu Court of Appeal's decision in Chan Wing represents the high water mark of judicial respect for international comity in the Pacific islands. In adopting and applying the orthodox principles for the granting of anti-suit injunctions and pleas of forum non conveniens, the court has accepted that international litigation is best placed in the natural forum. The decision also accepts that, when deciding whether it or a foreign court is the best place to deal with the dispute, the Vanuatu court should be more strict on itself than the foreign court. This is international judicial diplomacy that deserves the deepest respect. The earlier article in the Victoria University of Wellington Law Review revealed how, when making decisions about the appropriate forum for international litigation, courts in the Pacific islands had ignored or misapplied some important principles that were needed to ensure litigants were given a procedurally neutral setting for their litigation. Chan Wing addresses some of these issues directly. In relation to anti-suit injunctions they include: the need to prove that the foreign proceedings are vexatious and oppressive; the expectation that the foreign court might itself first be invited to stay the proceedings before it; a closer examination of the nature and purpose of the proceedings before the foreign 
court; and generally elevating the significance of lis pendens. ${ }^{93}$ In relation to forum non conveniens the Court of Appeal's decision also empties Naylor $v$ Kilham of any authority. This necessarily denies any legitimate role for the plaintiff-oriented principles of Voth $v$ Manildra Flour Mils Pty Ltd in Vanuatu, and removes other unsatisfactory aspects of Naylor: the foreign plaintiff rule; and the devaluation of lis pendens in proceedings for a stay or dismissal of proceedings.

The only real blemish in the decision in Chan Wing is the court's attempt to use the in personam jurisdiction it must have when granting an anti-suit injunction to improve the international enforceability of its own judgment. The decision is interesting in confirming that, as a matter of raw power, courts have this capability. So long as the plaintiff wants an injunction desperately enough to agree to honour a condition that he or she not resist the international enforcement of any local judgment the plaintiff may suffer, that judgment can be enforced anywhere in the world where there is potential for recognising foreign judgments - but without having to comply with the conditions set by the enforcing country for recognition. It is similar if, as a term of the injunction, that were required of the defendant, although the defendant is coerced into this position where the plaintiff has the choice of abandoning the injunction if wishing to challenge enforcement in another country. That there is jurisdiction and power to achieve this outcome is evident, but the quality of principles of jurisdiction that makes them, in Lord Goff's words, "civilised" is that they carry a responsibility to exercise self-restraint. ${ }^{94}$ The power is not to be exercised just because it is there. It may be that the Chan Wing court was aware that there must be self-imposed limits on its powers to improve the enforceability of its judgments unilaterally. After all, it did not try to enhance the enforceability of any judgment that might eventually have been made against the defendants. Further, given that there may not have been any counterclaim against the plaintiffs in Vanuatu, the condition imposed on the plaintiffs may have been meaningless. However, the jurisdiction to grant anti-suit injunctions is to be limited by principles of comity, and that would suggest that there be no attempt to modify the enforceability of local judgments in other countries. This necessarily means that Vanuatu judgments would have a lesser international circulation than many other countries' judgments do. Vanuatu is internationally entitled to refuse to improve the enforceability of foreign judgments within its borders by not participating in arrangements with other countries for the reciprocal enforcement of judgments. It can do so while, in terms of the private international law, remaining compliant with principles relevant to the comity of nations. However, it also means that Vanuatu courts are bound by both comity

93 Compare with Mount Kasi Limited v Range Resources Limited [1999] FJHC 57 (HC) [Mount Kasi].

94 Airbus Industrie GIE v Patel [1999] 1 AC 141 (HL) [Airbus]. 
and the national policy on judgments enforcement not to attempt themselves to improve the enforcement of Vanuatu judgments in other countries. 